\title{
VERSOS E GRITOS: MEMÓRIA POÉTICA DA GUERRA COLONIAL
}

\author{
Margarida Calafate Ribeiro \\ (Universidade de Coimbra)
}

Roberto Vecchi

(Universidade de Bolonha)

\section{RESUMO}

$\mathrm{O}$ artigo analisa a memória poética da experiência da Guerra Colonial identificando expressões díspares do poético: poemas de valor predominantemente documental; uma poesia da época que integra a Guerra Colonial e também a expõe pelo canto; e uma poesia de poetas da Guerra Colonial.

O arquivo poético construído pela Antologia da Memoria Poética da Guerra Colonial, organizada pelos autores deste artigo demonstra que só o advérbio "Ainda" - aquele com que Manuel Alegre fecha uma viagem sem regresso - mostra como a guerra continua por dentro das palavras, por dentro dos versos, denunciando a profundidade da inscrição da guerra no presente.

PALAVRAS-CHAVE: Guerra Colonial; Memória; Poesia; Trauma.

\section{ABSTRACT}

The article analyzes the poetic memory of the experience of Colonial Wars identifying disparate expressions of poetic: a sort of poems of documentary value; poetry of the era that integrates Colonial War and also exposes the theme on the protest song; and poetry from poets of the Colonial War.

The poetic archive made by the Anthology of Poetic Memory Poetics of Colonial Wars, organized by the authors of this article, shows that only the adverb Ainda/ Still -, one with which Manuel Alegre closes a voyage without return - shows how the war of continues inside the words, inside of the verses. It shows the depth inscription of the Colonial Wars in the Portuguese present time.

KEYWORDS: Colonial Wars; Memory; Poetry; TraumaEntre 1961-1974. 
Portugal manteve com as suas então colónias de Angola, Moçambique e Guiné-Bissau uma Guerra Colonial, mobilizando perto de um milhão de homens e tocando praticamente todas as famílias portuguesas. A experiência da participação portuguesa neste evento de indefinida colocação historiográfica, quer pela denegação que oficialmente o caracterizou, quer pela radical reformulação geopolítica do país que a partir dele se engendrou com a descolonização, tornou este acontecimento um dos mais complexos, mas também um dos mais trágicos eventos da contemporaneidade portuguesa. A experiência coletiva e individual da participação dos portugueses na Guerra Colonial teve, e continua a ter, o seu registo de expressão narrativa e crítica, ora através de testemunhos de variada matriz, ora através de estudos historiográficos e o seu registo estético nas mais variadas formas de arte - da pintura e escultura à narrativa, do cinema ao teatro, da música à poesia. Mas foi sem dúvida na literatura que o registo de reelaboração coletiva e individual do evento se tornou mais marcante, dando origem a mais de uma centena de romances e a milhares de poemas. Esta poesia, de autores direta ou indiretamente envolvidos na guerra, e elaborada, ou no momento da vivência do evento bélico, ou em seguida, enquanto espaço de memória e de elaboração pós-traumática, foi o objeto de atenção e estudo do projeto Poesia da Guerra Colonial: uma Ontologia do 'eu' Estilhaçado, que decorreu nos últimos anos no Centro de Estudos Sociais da Universidade de Coimbra ${ }^{1}$, de que resultou a Antologia da $\mathrm{Me}$ mória Poética da Guerra Colonial, publicada em Portugal em 2011, pela editora Afrontamento. Que tipo de poesia é esta? Quem são os seus autores? Este evento marcou a poesia contemporânea portuguesa? Que tipo de memória poética está registada nesta antologia?A memória poética surge de interseções entre ars poetica e ars reminiscendi estruturando uma enraizada tradição, baseada na ideia de "formularidade" da praxe da citação, da “arte alusiva” (CONTE, 1974, p. 44-45).

A memória poética articula-se, portanto, por combinação, acordo ou amálgama com a lírica moderna, gerando configurações e formas efetivamente próprias. Talvez por essas razões seja necessário pensar na memória poética não apenas em termos teóricos, mas associando-lhe um acontecimento que a torne mais imediatamente pensável. Esse é, por exemplo, o caso da poesia da Guerra Colonial, que apresenta, por um lado, um corpus textual muito amplo, ainda não delimitado, que conserva rastos de experiências e, por outro, memórias traumáticas como poucos outros documentos que se referem ao conflito. O objetivo, de fato, é que a conjugação da memória poética com a lírica moderna, ou melhor, com a cultura não apenas erudita, mas também com a cultura de massa, reponha a poesia como um material fundador da memória contemporânea, cujo efeito reconstitutivo, diga-se de passagem, remete justamente para as aporias do contexto pós o 25 de Abril e para a urgência de retecer uma memória comum largamente dilacerada e singularmente fragmentária. 
Assim, no heterogéneo corpus da poesia da Guerra Colonial, para além do cânone de poetas da Guerra Colonial, - Manuel Alegre, Fernando Assis Pacheco e José Bação Leal - praticamente todas as vozes poéticas da época se debruçaram sobre o evento trágico: Fiama Hasse Pais Brandão, Luíza Neto Jorge, Maria Teresa Horta, Jorge de Sena, Nuno Júdice, João Miguel Fernandes Jorge, Gastão Cruz, Pedro Tamen, Ruy Belo, Casimiro de Brito, Ana Hatherly, António Gedeão, Alexandre O’Neill, José Manuel Mendes e tantos outros inscreveram na sua poesia a contemporaneidade da guerra sobre o seu tempo ou a sua memória. Mas o que talvez seja menos conhecido é como a Guerra Colonial condicionou através de formas poéticas o campo da cultura de massas.

Nesta medida, importa considerar o imenso grupo de poetas "em armas", que estiveram na Guerra Colonial e que entregaram à forma lírica sentimentos e emoções, medos e desejos, pesadelos e sonhos, culpas e raivas, da sua experiência, hoje publicados em edições de autor, de pouca circulação ou em livros coletivos que combinam de modos ingénuo ou mais advertido vários géneros poéticos. Trata-se de um grupo de vozes absolutamente heterogéneo que encontrou no meio poético um modo de simbolizar o nicho duro e frequentemente opaco, em termos de significação, de uma experiência na maioria dos casos sofrida e alienada, ou ainda um modo de exprimir os efeitos posteriores da idealização que pode ocorrer numa fase da vida que, para o bem ou para o mal, se identifica com a juventude e que só retoricamente se liga a antigos ideais de patriotismo, nacionalismo e glória agora esvaziados de conteúdo. De facto, para a esmagadora maioria, a Guerra Colonial enquanto experiência também traumática ficou poeticamente registada como um fantasma por esconjurar acenando à dimensão do luto, da perda, da saudade de uma pessoa que se foi, de uma juventude hipotecada, de uma partida contrariada, de um regresso que não aconteceu, expresso em milhares de versos que frequentemente povoam o território opaco da escrita íntima - poemas, cartas, diários, etc. - ou aparecem nas margens de pequenas publicações dispersas, ou ainda na memória pública do canto de intervenção, dos cancioneiros ou dos hinos que povoam a memória coletiva da Guerra Colonial.

A questão será então se uma reflexão sobre a memória poética tem possíveis elos em comum com a construção de uma memória cultural e, sobretudo, pública, considerando a tensão que marca a relação entre memória e poesia. O caso em jogo, o da poesia da Guerra Colonial, permite aparentemente responder de modo positivo à pergunta. Define-se de facto uma dimensão cultural nesta poesia de cariz erudito e, sobretudo, popular a que se juntam os cancioneiros que nasceram, ora na oposição frontal ao conflito armado, ora no âmago das Forças Armadas Portuguesas, como foi o caso do conhecido "Cancioneiro do Niassa". Ambos projetam esta memória poética no âmbito dos quadros sociais da memória coletiva, como Maurice Halbwachs (1968), Jan Assmann (1997) e Michael Pollack (1989) a discutiram. No entanto, poderíamos, por exemplo, argu- 
mentar que as letras do "Cancioneiro do Niassa", assim como uma massa considerável da produção poética que lhe foi contemporânea, radicalizam o sentido próprio do poético, ou seja, de facto põem em questão o que é a poesia. O que ocorre na construção dessa memória poética praticamente ilimitada que desafia e coloca sob suspeita as categorizações estéticas - que provavelmente excluiriam obras como o "Cancioneiro do Niassa" e uma vasta parte da poesia da Guerra Colonial de autores não consagrados - é uma tensão entre a dimensão singular e dolorosa da experiência mediada e uma forma poética que universalize e amplie o registo, às vezes direto, do desabafo emocional. Assim, nesta memória poética da Guerra Colonial, encontramos díspares expressões do poético a partir de um contexto comum: um "material em forma de poesia", no sentido em que possui um valor predominantemente documental; uma poesia da época que integra a Guerra Colonial e também a expõe pelo canto; e uma poesia de poetas da Guerra Colonial.

Do ponto de vista do conteúdo e do valor poético, na Antologia publicada desenha-se uma sistematização possível entre aquilo a que chamamos os textos-reflexo desta guerra - testemunhos de uma experiência por vezes ideologicamente marcada - e os textos-consequência, isto é, aqueles que ultrapassam o carácter meramente testemunhal de uma realidade vivida para, a partir dessa experiência, elaborarem uma reflexão mais ampla sobre o vivido num sentido individual e coletivo. Uma poesia, portanto, a vários tempos, elaborada a partir de vários lugares (geográficos, sociais. políticos, ideológicos e de género), mas tematicamente unida pela Guerra Colonial.

\section{“EU QUERIA APENAS DIZER GARE MARÍTIMA DE ALCÂNTA- RA", “LISBOA", NUM ANO QUALQUER ENTRE 1961 E $1974{ }^{2}$}

As primeiras notícias dos lugares da guerra em Angola vêm logo em 1963, dos matos de Nambuangongo, pela voz poética de Fernando Assis Pacheco. Publicados no seu livro de estreia, Cuidar dos Vivos, "O poeta cercado" e "Há um veneno em mim" são os dois primeiros poemas de denúncia ativa da guerra em Angola. A estes viriam a juntar-se, Poesias e Cartas, de José Bação Leal, publicadas postumamente em 1966 e 1971, Praça da Canção (1965) e O Canto e as Armas (1967), de Manuel Alegre, Cau Kiên: Um resumo (1972), e Viagens na Minha Guerra (1972) também de Assis Pacheco, Três Natais (1967), de José Correia Tavares, entre alguns outros. Poemas-notícias que quebravam o tempo de silêncio e colocavam sob suspeita o Portugal sonâmbulo de Salazar, revelando uma realidade povoada de "miséria", "pedaços", "corpos", cadáveres", "minas" e mostrando "outras verdades" sobre as virtudes de a "tropa fazer dos jovens uns homens", sobre a nação pluricontinental e plurirracial, sobre os "enfeitiçados selvagens a soldo do comunismo", sobre os políticos de Lisboa, sobre o silêncio que se fazia sobre a palavra "guerra". 
O tempo era de múltiplos silêncios e eram várias as deslocações simbólicas e temporais utilizadas pelos poetas, transferindo as imagens da Guerra Colonial, ora para outros momentos da história de Portugal como na relação entre o desastre de Alcácer Quibir e os terrenos da Guerra Colonial que a poesia de Frey Ioannes Garabatus (António Quadros) e de Manuel Alegre sustentam - ora para outras geografias - como é o caso das aproximações sugeridas entre o conflito que Portugal e as suas colónias viviam e Hiroxima ou Vietname, não só dadas pelas antologias organizadas por Manuel Simões e Carlos Loures, mas também nos poemas de Assis Pacheco, Egito Gonçalves, António Rebordão Navarro e outros poetas. Como denominador comum destas sugestivas deslocações impõe-se a imagem de fim, seja na memória coletiva portuguesa, com a evocação do episódio de Alcácer Quibir, onde se escreveu um epitáfio à nação portuguesa imperial, seja na memória coletiva do Ocidente, com a evocação de Hiroxima ou Vietname, onde o mundo escreveu os limites de uma violência física e psíquica, que afinal não se tinham esgotado no Holocausto. Parecia assim ficar sugerido por estas aproximações, já não o pressentimento do naufrágio da pátria portuguesa - que só uma poesia nacionalista retórica de reinvenção imperial sustentava ${ }^{3}$ - mas a certeza iminente de um naufrágio pessoal e coletivo, como privadamente anunciava Assis Pacheco a seu pai: "é por estes matos que tudo foge. A guerra perdeu a medida" (1996, p. 50). Esta poesia de tom antissituacionista, anticolonialista e intervencionista, escrita e publicada nos limiares da clandestinidade ou em edições de autor com tiragens pequeníssimas e frequentemente apreendidas pela PIDE, não só não subscrevia as visões do regime, como as interrogava e punha em causa, a partir da experiência vivida na periferia imperial em guerra.

São relevantes, para uma apreciação da poesia da Guerra Colonial como um todo, as mensagens dos três primeiros poetas que referimos, cujas poesias e cartas marcaram de forma distinta o testemunho desta guerra na literatura portuguesa anterior ao 25 de Abril de 1974: José Bação Leal, enviado em Novembro de 1964 para Moçambique, onde viria a falecer num acidente, tornando-se a sua voz no símbolo de uma geração "habitada pela mesma ferida" e sacrificada numa guerra sem sentido; Assis Pacheco e Manuel Alegre, unidos por várias vicissitudes da vida e da poesia. Mas, enquanto nas cartas e poemas de José Bação Leal e na poesia de Assis Pacheco o tom intimista e performativo do testemunho do poeta que roga "Por favor olha: onde estive, onde o capim passava do ombro, a morte passava, e a melancolia" (PACHECO, 1996, p. 49) ou do poeta que escreve "Sou neste momento um cadáver em fúria [...] Estou farto, farto, farto!" (LEAL, 1971, p. 144 e 85) nos compromete com as experiências das suas guerras, sem com isso pretenderem apresentar-se como porta-vozes dos que passaram experiência semelhante, como sublinhou Fernando J. B. Martinho (1995, p. 25), relativamente a Assis Pacheco, na poesia de Manuel Alegre encontramos um acentuado ritmo e sentido epopeico que dá voz a um sentimento coletivo de perdição de que o poeta se afirma portador. É, 
de certa forma, o sopro dos ventos de Alcácer Quibir, metáfora sobre a qual Manuel Alegre assenta a sua poesia, e a aragem do "plaino abandonado" de todas as guerras, que podemos utilizar para caracterizar genericamente estas duas linhas poéticas, que encerram, não tanto posições éticas e políticas distintas, mas, sobretudo, distintas funcionalidades morais e literárias, que entre si se entrecruzam e perpassam toda a literatura relativa a esta guerra.

Nas Poesias e Cartas de José Bação Leal, publicadas em 1966 e 1971, dá-se testemunho da experiência do jovem poeta como soldado involuntário na Guerra Colonial. Nelas, não é tanto a dimensão geográfica do processo de desterritorialização inerente à ida para a guerra que perturba o poeta, mas a assustadora dimensão humana e política que esta desterritorialização assume num sentido imediato e retrospetivo. Assim, temos um novo território, África, como um espaço que o fascina, enquanto espaço natural e cultural, e o repugna enquanto construção colonialista visível; a África dos quartéis e da guerra e da profunda miséria humana que os povoa; e, finalmente, a consciência psíquica e física do que era Portugal perante tão vasto império e da distância a que Portugal estava de toda a realidade por si experienciada. "Aí deve-se ignorar o que se passa", "ficas também a saber" são frases que pautam as suas cartas e revelam uma vontade ativa de dar testemunho sobre o que estava a acontecer em África e a si mesmo e, ao fazê-lo, comprometem o seu leitor com a realidade revelada pelo seu testemunho.

Fernando Assis Pacheco partiu para Angola no dia 25 de Abril de 1963 a bordo do navio Niassa, rumo a Nambuangongo. Ao longo dos meses em que esteve no aquartelamento de Nambuangongo foi enviando ao pai as suas impressões da guerra, fazendo assim dura prova da sua ausência e aliviando-se do drama que estava vivendo pela passagem do testemunho àquele que se tinha tornado o seu pai-confessor. Em Musa Irregular - publicação que reúne a obra completa de Assis Pacheco em 1991 - a finalizar Cuidar dos Vivos encontramos uma secção intitulada "Versos que o Autor Mandou de Nambuangongo ao Editor". Na correspondência enviada ao pai, Assis Pacheco incluiu dois poemas, e o seu pai, que viria a financiar a primeira edição de Cuidar dos Vivos, colocou-os no final do livro sob o título inicial de "Nambuangongo, 1963", obedecendo assim ao compromisso epistolar original dos poemas e, porventura, esconjurando com o filho os fantasmas desse espaço de guerra que lhe trazia notícias de um filho "envenenado". Todavia, o segundo livro de Assis Pacheco, também sobre a experiência da guerra, Câu Kiên: Um Resumo, foi apenas publicado em 1972. Foram, portanto, precisos nove anos para que o silêncio do poeta após o regresso se tornasse matéria escrita, ou seja, para que o eu poético pudesse coincidir com uma experiência/ memória autobiográfica de dor, morte, horror e guerra que o livro apresenta. Câu Kiên: Um Resumo é composto por um conjunto de poemas onde a nomenclatura vietnamita disfarça, habilmente, os matos angolanos em que a guerra se desenrolava. Esta analogia, desvendada em 1976 com a publicação de Catalabanza, Qui- 
lolo e Volta em que os topónimos e o vocabulário vietnamita de Câu Kiên: Um Resumo são substituídos pelos originais angolanos, constituía a forma geracional, como acima assinalámos e o poeta fazia questão de sublinhar, de falar de Angola falando do Vietname ou de Hiroxima ${ }^{4}$. Catalabanza, Quilolo e Volta, datado de 1972, na coletânea A Musa Irregular (1991 e 1996), indo assim ao encontro da sua data moral, pode ser lido como uma longa conversa-testemunho entre o poeta e o seu pai-pátria, sobre o que era aquela guerra, a sua falta de virtude e heroísmo e o estado em que deixava os homens. Ao longo da poesia de guerra de Fernando Assis Pacheco, elaborada ora num tom melancólico, que está de luto pelas perdas, ora num tom sabiamente irónico, parodístico e autoirónico que impede o poeta de endoidecer de solidão e desespero, a mensagem pronunciada enuncia a mentira que se vivia no país, e revela a condição trágica do poeta enquanto elemento desgraçadamente ativo na referida mentira, como explicitamente surge no poema "Por Estes Matos". Neste poema, como em muitos outros do poeta, assistimos à denúncia da mentira da guerra, ecoando o que o malogrado poeta inglês da Primeira Grande Guerra, Wilfred Owen designou como "The old Lie: Dulce et decorum est /Pro patria mori” (OWEN, 1983, p. 140) e que é, na verdade, a "old lie" de todas as guerras.

Outro foi o percurso poético e pessoal de Manuel Alegre, a quem Assis Pacheco diria do meio das Viagens na Minha Guerra que "É por estes matos que foge a canção" (PACHECO, 1996, p. 49), evocando assim o poeta e amigo que em 1965 o tinha colocado em Praça da Canção depois de ler Cuidar dos Vivos e que iria ser o portador da voz da "canção" de uma juventude que rejeitava a guerra. Desde Praça da Canção (1965), a voz poética de Manuel Alegre surge, como a voz de um "Camões em Restelo", clamando por um outro Portugal que não o que lhe é veiculado pela mitologia salazarista, e perspetivando este "tempo triste" num redimensionamento do tempo da história de Portugal, contada sob o olhar daqueles cujas histórias não vêm na História: o Manuelinho de Évora, o Pedro-Soldado, o José, a Linda, o João-que-foi-à-Índia, a Rapariga-do-País-de-Abril que compõem a "galeria de heróis" de Praça da Canção. Neste singular espaço de resistência, em que o discurso poético nasce de uma relação simbólica entre o discurso político e o discurso histórico, Manuel Alegre constrói um discurso de portugalidade alternativo, dando assim as fundações históricas e políticas para um genuíno processo revolucionário, chamando toda a sua geração à luta contra o novo Alcácer Quibir que se alevantava nos matos africanos e contra a "noite que invadia os homens do país".

Numa linha próxima de Assis Pacheco, em Praça da Canção temos a denúncia da guerra como o prolongamento desmedido e monstruoso do "país triste" de Salazar e a inscrição de Nambuangongo como o lugar símbolo de uma vivência coletiva de morte física e espiritual, como aparece no icónico poema. Neste poema - ao invés da corrente geracional que utilizava, ora o exemplo de Hiroxima, ora o do Vietname para, sub-repticiamente, falar de Angola - Manuel Alegre utiliza o poderoso eco 
moral e textual de Hiroxima para falar abertamente da guerra em Angola, construindo no poema "Nambuangongo meu amor" uma espécie de "Hiroxima moral" portuguesa, como lhe chamou Eduardo Lourenço (LOURENÇO, 1999, p. 37).

Em O Canto e as Armas, de 1967, o canto eleva a sua voz: alarga-se a temática, sobe de tom a revolta, afirma-se a voz do poeta como a voz da nação. Como Camões, Manuel Alegre oferece o seu canto aos seus contemporâneos, para que com ele preencham o esvaziado tempo presente que, como o tempo camoniano, na leitura de Helder Macedo (1998, p. 125), "passa lento" e se revelem capazes de cumprir o "novo atrevimento" a que os poemas apelam, mostrando-se assim aptos a rumar a um novo tempo que acabe com o silêncio e "a noite dentro dos homens do meu país", com as partidas para França, com os Lusíadas Exilados, com os homens morrendo nos campos de Nambuangongo/Alcácer Quibir, e assim se revelando merecedores da História com um $H$ maiúsculo. Como sublinhou Eduardo Lourenço, "para não assistir 'à morte do Rei' escreveu Manuel Alegre a epopeia por defeito de O Canto e as Armas" (1999, p. 42), onde o poeta evoca não só "as colunas que partiam de madrugada" para os terrenos de Quipedro/Nambuangongo, mas também a partida para Alcácer Quibir, a caminho do desastre que foi sempre "ir morrer além do mar por coisa nenhuma”. Não só pelas razões políticas evidentes que, à data, a sua obra contemplava, mas sobretudo pela maneira ética em que essas mesmas razões foram convertidas em razões estéticas, a poesia de Manuel Alegre faz parte da memória de uma geração que com ele partiu a bordo desse imenso barco fantasma. Se no discurso poético de Assis Pacheco ou na correspondência de José Bação Leal a fórmula "a guerra perdeu a medida” é perspetivada numa dimensão pessoal, em que assistimos ao esfacelamento do ser num intenso testemunho da guerra vivida, sem utopias de redenção, na poesia de Manuel Alegre ela é vivida na sua dimensão coletiva e nacional, como um espaço simultaneamente síntese de todas as marginalidades criadas pelo Estado Novo e de despoletamento inevitável da luta por um espaço português alternativo em que a utopia política nacional se abre como espaço de redenção. Embora todos os discursos se situem num tom dialógico que vem dar notícias e desinquietar, o discurso de Assis Pacheco compromete-nos com o testemunho do poeta, enquanto o de Manuel Alegre, pela interpelação direta que dirige e pelo ritmo melódico em que é pronunciado, sabiamente lírico, épico, elegíaco e intervencionista, exigiu, àqueles que o leram e ouviram na época, uma resposta

\section{ANGOLA 61/ PORTUGAL 61/ POESIA 61}

No mesmo ano de 1961 em que a guerra começava em Angola surgiam em Maio, as plaquettes de Poesia 61, reunindo cinco jovens poetas: Fiama Hasse Pais Brandão, Luiza Neto Jorge, Maria Teresa Horta, Casimiro de Brito e Gastão Cruz. Unia-os a juventude, um interesse editorial comum e alguns signos que perpassam as suas poesias, sem contudo deles fazerem um grupo, como será aliás atestado pelos percursos individuais e individualizados que vão traçar no panorama da poesia dos anos $60 \mathrm{em}$ diante. 
Do lugar onde estavam diziam ser o "cais dos barcos pequenos de papel", onde "dentro de um secular sossego", se dormia e apodrecia, assumindo-se eles próprios, enquanto cidadãos, como "a escultura de amanhã" (CRUZ, 1961, p. 16; JORGE, 1961, p. 3-6) ${ }^{5}$. À expressão de dor deste tempo de futuro hipotecado e de morte espiritual, expressa em várias poéticas dos anos $50^{6}$, Poesia 61 acrescenta um importante dado epocal num sentido semântico e histórico: a expressão de uma violenta fragmentação espiritual e física, tematicamente expressa, por um lado, no questionamento de um imaginário coletivo ligado à aventura marítima; por outro lado, no questionamento de uma moral tradicional, fechada e castradora, simbolizada na "casa portuguesa" e nas relações familiares, que por sua vez projeta e refrata as instituições públicas que compunham a sociedade. Este questionamento é veiculado, de um ponto de vista semântico, pela obsessiva referência a partes, fragmentos de corpos, cadáveres, pedaços de vida, morte, palavras cortadas, sugerindo um estilhaçamento das matérias referidas, e, de um ponto de vista sintático, na contenção vocabular e expressão textual fragmentária que caracteriza esta poesia.

Em Portugal Maio de Poesia 61, Jorge Silveira (1986) ao analisar as conexões entre o texto e a história, por um lado, e o contexto poético de Poesia 61, por outro, mostra-nos como esta poesia correspondeu a um estado de espírito de prenúncio de fim de um tempo, não só de um império e de uma identidade nacional aprendida desde os bancos da escola, mas também de uma moralidade nacional e familiar que já não correspondia às expectativas da época e que a guerra iria modificar profundamente. $\mathrm{O}$ país "do eterno Portugal meu berço (de) inocente que a pedagogia do regime destilava como mel obrigatório desde o banco da escola primária à Universidade" (LOURENÇO, 1982, p. 35) "desbotou/ no mapa das escolas" (JORGE, 1961, p. 4) e os "seres sitiados" que o habitam falam obsessivamente de morte, sofrimento, corpos mutilados ou mortos precisamente porque estão em busca do amor, da vida, da esperança que o tempo mortificante insiste em lhes furtar (CRUZ, 1999, p. 34), como explicitamente nos aparece na poesia de Luiza Neto Jorge, que situa esta luta pela libertação no plano quotidiano da vida familiar, social e institucional. Num país onde em nome da defesa da integridade nacional se pedia o corpo e a vida aos homens, e a família (e a igreja) resguardava o corpo das "meninas de saia rodada", no poema "Balada apócrifa”, Luiza Neto Jorge propõe a subversão da divisa dos militares (“a vida pela pátria”), e consequentemente da guerra por eles administrada, com o oferecimento dos corpos das meninas aos soldados. Este oferecimento constituía de facto uma afirmação dupla de subversão: da sexualidade, reprimida pela sociedade, e da morte que a guerra trazia, subvertendo assim de duas maneiras distintas, mas complementares, o que quotidianamente interditava a vida e a liberdade dos jovens e de todos os homens e mulheres deste tempo (SILVEIRA, 1986, p. 178).

Por seu turno, a mudança, historicamente substantiva, contida por exemplo em alguns poemas de Fiama Hasse Pais Brandão, em que passamos de um tempo de barcos reais ou míticos a barcos cheios de sangue, 
leva à mudança pessoal e coletiva de perceção do cais da partida que é Portugal em Barcas Novas. Trata-se de uma partida rumo à morte e, portanto, sem regresso como mais tarde aparecerá no grande mural de interiores que são as Novas Cartas Portuguesas, publicadas com grande escândalo e proibidas pela censura em 1972, não apenas pelas múltiplas "clausuras" femininas, visíveis e invisíveis, expostas, mas também pela denúncia nelas feita do estado em que os homens (não) vinham das Áfricas ${ }^{7}$.

A importância decisiva de Poesia 61 nas vozes poéticas da Guerra Colonial marca a tendência de uma poesia de pendor universitário que vai conjugar uma revisitação dos temas da partida, da canção medieval e dos temas clássicos com o seu tempo, um tempo de guerra e de censura, que é preciso denunciar para que termine. José Manuel Mendes, Luís Guerreiro, Manuel Simões, Nuno Júdice, Deana Barroqueiro, José Niza e tantos outros poetas presentes na Antologia da Memória Poética da Guerra Colonial vão seguir esta linha de reescrita dos temas e poemas clássicos, não para lhes prolongar uma vida agonizante de que já não gozam - como acontece com a poesia apologética da guerra e a reutilização abusiva de Camões e dos signos da epopeia ou da história dos Descobrimentos -, mas sim para denunciar os temas do seu tempo, nomeadamente a partida sem regresso para a guerra, a épica camoniana lida às avessas, a eterna e vã espera da mulher portuguesa no cais, a viagem rumo à morte em barcas de armas. Um canto de hoje e de sempre que ecoa, na cultura de Portugal, desde as cantigas ainda em galaico-português.

\section{EM DOR MAIOR - O CANTO}

Qual é o sentido de considerar as canções a que a Guerra Colonial deu origem, seja na sua vertente de canto de intervenção, de canção popular, rock, hinos ou cancioneiros de guerra no âmbito da memória poética da Guerra Colonial? Ou melhor, será que podemos traçar elos entre a construção de uma memória cultural, e sobretudo pública, e estas produções culturais que combinam algo de muito tradicional - uma tendência para a composição poética que muitas vezes valoriza um manancial folclórico e subjetividades líricas, um gosto para a expressão em verso - associado a uma forma própria da cultura de consumo (a canção, a trilha musical em voga), que serve como vetor da criação?

Nas canções e cancioneiros, que nasceram no âmago da Guerra Colonial, encontra-se a expressão de uma vasta dimensão cultural, que projeta a memória poética no âmbito dos quadros sociais da memória coletiva. São várias as gerações de portugueses para quem, por exemplo, ouvir o hino "Angola, é nossa" tem um significado emocional e quase visual imediato. Imagens como o cais, as despedidas, a chegada a África, a guerra, o amigo que se deixou para trás, a namorada, a mulher, a mãe impõem-se entre a emoção, a revolta ou a saudade gerando uma memória comunitária que assimila a experiência singular e irredutível da dor. O mesmo se pas- 
sa com algumas canções de intervenção cantadas por Adriano Correia de Oliveira, Zeca Afonso, as canções de José Mário Branco, como a célebre "Ronda do Soldadinho", Luís Cília, Tino Flores ou Sérgio Godinho, que, em Portugal, mas sobretudo no exílio, construíram a canção de luta contra a guerra, a falta de liberdade e todas as formas de opressão e assim denunciaram, também na Europa, a violência da Guerra Colonial; ou, quase que por aparente oposição, com o enorme arquivo de cancioneiros militares de que o exemplo mais conhecido e mediatizado é o "Cancioneiro do Niassa"; ou, finalmente, com a reativação de canções ligadas à memória da Primeira Grande Guerra ou ao serviço militar que antes da Guerra Colonial já era cumprido nas ex-colónias, e que pelo seu conteúdo bélico e o seu apelo à paz num mundo em guerra, adquiriram novo significado no contexto do conflito iniciado em 1961, como é o caso do poema de Fernando Pessoa "O Menino de sua Mãe", cantado por cantores tão diversos como Dário de Barros ou Luís Cília, "Menina dos Olhos Tristes", ou ainda "Receita para fazer um Herói", ambos de Reinaldo Ferreira e anteriores à Guerra Colonial. A reativação destes poemas, agora musicados, torna-se particularmente interessante pelas situações repetidas que evocam - o menino de sua mãe que jaz morto e arrefece, traz o tópico da guerra como um fenómeno que desfaz a obra de maternidade e elege a figura da mater dolorosa como um símbolo de apelo à paz no interior da guerra; e a menina "dos olhos tristes" que espera no cais o soldado que não volta do outro lado do mar - gerando tópicos que fazem parte de todas as guerras e que consolidam uma memória comunitária.

Nas suas várias formas mais eruditas ou mais populares, mais de música ligeira ou de fado, o heterogéneo arquivo poético-musical representa a forma de poesia da Guerra Colonial que melhor conjuga e ativa as relações antigas entre poesia, canto e memória e aquela que gera mais emoção partilhada e partilhável na memória individual e na memória coletiva portuguesa da Guerra Colonial. Nesta poesia, cantada por gerações de jovens de vidas ceifadas pela guerra, no interior das academias, das fábricas ou das aldeias, na distância e abandono do exílio, no mato ou nos quartéis onde também os soldados entoavam estas letras, trauteavam estas músicas estava também a semente da denúncia e da indignação. Apesar da vigilância e da censura, a par das canções e dos êxitos da época ia-se também cantando Zeca Afonso ou Adriano Correia de Oliveira, José Mário Branco ou Luís Cília, músicas muitas vezes também utilizadas em espetáculos improvisados por grupos de soldados que, sendo músicos, e no âmbito da legislação Alerta já, passavam o seu tempo de guerra em missões de entretenimento das tropas cantando para os colegas soldados. Escrita tantas vezes por quem viveu a experiência da guerra ou por quem estava na "outra guerra" - a da deserção e do exílio -, esta poesia estava investida de uma função de denúncia, desta situação trágica e humanamente devastadora, de alerta contra o esquecimento, e de revolta contra quem, tendo o poder de terminar a Guerra, a continuava para dela tirar os dividendos 
políticos que eram, acima de tudo, a manutenção do próprio regime. De uma forma ou de outra, trata-se de textos que, no momento de conflito e pela sua dimensão performativa e coletiva, obrigavam a repensar a guerra em que se estava envolvido. Hoje levam-nos a refletir sobre a importância da memória da guerra, enquanto espaço de criação e preservação de liberdade e cidadania. Um texto como "A Bola", de Jonas Negalha, cantado por Luís Cília, que traz a terrível denúncia da violência do massacre, constitui um dos mais fortes e violentos poemas da Guerra Colonial; ou "Fotos do Fogo", de Sérgio Godinho, que colocava o problema de como contar a história (e que história contar) às gerações futuras, a partir de um álbum de fotografias de guerra; "Romance de Pedro Soldado", de Manuel Alegre, cantado por Adriano Correia de Oliveira, que evoca a partida dos soldados para esta e para todas as guerras da história de Portugal ("Já lá vai Pedro soldado/ Num barco da nossa armada/ E leva o nome bordado/ Num saco cheio de nada/ Triste vai Pedro soldado" (ALEGRE, 1999, p. 120-121), mas também os mais populares "Lenda de Nambuangongo", de José Cid, ou "Lá longe onde o sol castiga mais", de Paco Bandeira, são textos que obrigavam e obrigam ainda hoje quem ouve a questionar a Guerra Colonial e, a partir dela, a legitimidade de qualquer guerra.

Este foi, aliás, o lastro que as gerações futuras - nomeadamente a geração dos cantores de rock dos anos 80 - apanharam da Guerra Colonial, evocando-a nas suas letras, não só para dar uma palavra de conforto e reconhecimento à geração dos seus pais, mas também para, a partir desta experiência, defender a paz e afirmar a objeção de consciência que então se discutia. Canções como "Aquele Inverno", de Delfins, "O Trolha da Areosa", de Rui Veloso ou "Aerograma”, de Trovante evocam a experiência da Guerra Colonial para reclamar a paz e o pacifismo como ideologia e como opção de cidadania.

De certo modo, a partir de uma vertente cultural, também estas canções exercem uma luta contra o esquecimento, integram uma memória poética do que foi, e do que ainda é, a Guerra Colonial. Reconfiguram-se assim as relações entre trauma e memória coletiva, mediadas por imagens e formas poéticas, que podem ser reativadas inclusive na sequência de contextos históricos variados. Aliás, esta sequência, noutras circunstâncias, mas sempre marcadas por traumas e perdas, foi denominada pelo historiador de arte alemão Aby Warburg "património de sofrimento"8 da humanidade.

Se assim for, na imaginação da memória poética da Guerra Colonial, no seu ditado lírico, de versos improvisados ou meticulosamente criados, é possível detetar rastos de um arquivo da dor que procura, às vezes com êxito outras vezes não, tornar-se dizível, ou pelo menos manifesta a intenção de dizer. É este "património de sofrimento" que a leitura da poesia da Guerra Colonial tenta expor e valorizar, sobretudo pela contribuição que a sua reinscrição pode oferecer à construção de uma futura memória 
pública partilhada. Uma memória comum que se capta entrelaçando as múltiplas vozes e tonalidades, como apresentado na Antologia da Memória Poética da Guerra Colonial. Uma memória, portanto, que já está concreta e potencialmente presente e que se pode agora ouvir, inclusive em seus silêncios e vazios, nos versos produzidos, escritos, cantados.

\section{AINDA}

Qual será o tempo de uma memória comum (não só poética) sobre este evento sombrio e iniciático, gravado em corpos ou em memórias feridas e mutiladas, à espera de um resgate efetivo e público? A resposta, como ensinam também os poetas, encontra-se num advérbio, aquele com que Manuel Alegre fecha a viagem. Ainda. "Ainda" mostra como a guerra continua por dentro das palavras, por dentro dos versos. Ele ativa um novo processo que atualiza o tempo da guerra e mostra a profundidade da sua inscrição no presente. Poder-se-ia também reiniciar uma viagem às avessas, onde as palavras surgem na contraluz das paisagens africanas como ruínas de um tempo que se perdeu, de uma idade que já não é, mas que talvez possa encontrar, nos sons e na arrumação aparente da forma poética, sobrevivências inesperadas, resistências surpreendentes, brilhos ténues e precários, mas que bastam para tornar menos tenebroso um tempo desapossado e alheio, que reluta em se encontrar numa memória comum.

As nossas frases estão cheias de picadas de minas a explodir nos substantivos por dentro do silêncio há emboscadas não sabemos sequer se estamos vivos. Os helicópteros passam nas imagens a meio de uma vírgula morre alguém e os jipes destruídos estão nas margens do papel onde talvez para ninguém se vão escrevendo estas mensagens.

(ALEGRE, 2008: 54)

\section{REFERÊNCIAS BIBLIOGRÁFICAS}

ALEGRE, Manuel. Obra Poética. Lisboa: Dom Quixote, 1999.

ASSMANN, Aleida. Ricordare: Forme e mutamenti della memoria culturale. Bologna: il Mulino, 2002.

ASSMANN, Jan. La memoria culturale: scrittura, ricordo e identita politica nelle grandi civilta antiche. Torino: Einaudi, 1997.

BARRENO, Maria Isabel; HORTA, Maria Teresa; COSTA, Maria Velho da. Novas Cartas Portuguesas. Lisboa: Editorial Futura, 1974. 
BRANDÃO, Fiama Hasse Pais; BRITO, Casimiro de; CRUZ, Gastão;

HORTA, Maria Teresa; JORGE, Luisa Neto. Poesia 61. Faro: E. de A, 1961.

CONTE, Gian Biagio. Memoria dei poeti e sistema letterario: Catullo, Virgilio, Ovidio, Lucano. Torino: Einaudi, 1974.

CRUZ, Gastão. Poemas Reunidos. Lisboa: Dom Quixote, 1999.

EMÍLIO, Rodrigo (org.). Vestiram-se os poetas de soldados: canto da pátria em guerra. Coimbra: Cidadela, 1973.

GOMES, Pinharanda (org.). O Corpo da Pátria: Antologia poética sobre a Guerra do Ultramar 1961-1971. Braga: Pax, 1971.

HALBWACHS, Maurice. La mémoire collective. 2. ed. Paris: Presses Universitaires de France, 1968.

LEAL, José Bação. Poesias e Cartas. Porto: Tipografia Vale Formoso, 1971.

LOURENÇO, Eduardo. O Labirinto da Saudade. Lisboa: Dom Quixote, 1982.

- Manuel Alegre ou a Nostalgia da Epopéia. In: ALEGRE, Manuel. Obra Poética. Lisboa: Dom Quixote, 1999, p. 31-44.

MACEDO, Helder. Viagens do Olhar: Retrospecção, Visão e Profecia no Renascimento Português. Porto: Campo das Letras (com Fernando Gil), 1998.

MARTINHO, Fernando J.B.. A confissão e a guerra: uma leitura de Catalabanza, Quilolo e Volta, de Fernando Assis Pacheco. In: SIMÕES, Manuel \& VECCHI, Roberto (orgs.). Dalle Armi ai Garofani: studi sulla letteratura della Guerra Coloniale. Roma: Bulzoni Editore, 1995, p. 21-28.

MARTINS, Fernando Cabral. O Trabalbo das Imagens. Lisboa: Aríon, 2000.

OWEN, Wilfred. The Complete Poems and Fragments. London: Chatto \& Windus, The Hogarth Press and Oxford Universty Press (edição de Jon Stallworthy), 1983.

PACHECO, Fernando Assis. A Musa Irregular. Porto: Asa, 1996. Walt ou o frio e o quente, Lisboa: Bertrand, 1979.

POLLAK, Michael. Memória, Esquecimento, Silêncio. Estudos Históricos, 2(3), p. 3-15, 1989.

SILVEIRA, Jorge Fernandes da. Portugal Maio de Poesia 61. Lisboa: INCM, 1986.

Recebido para publicação em 12/05/12.

Aprovado em 30/06/2012. 


\section{NOTAS}

1 Este projeto decorreu de 2007 a 2010, sob orientação científica de Margarida Calafate Ribeiro e Roberto Vecchi, com a assistência de investigação de Luciana Silva e financiamento da Fundação da Ciência e Tecnologia.

2 Citação de Fernando Assis Pacheco do texto da contracapa de Fernando Assis Pacheco, Walt ou o frio e o quente (1979).

3 Veja-se as antologias O Corpo da pátria: antologia poética sobre a guerra no ultramar, 1961-1971 (1971), organizada por Pinharanda Gomes e Vestiram-se os poetas de soldados: canto da pátria em guerra (1973), organizada por Rodrigo Emílio.

4 Disto são exemplo as já referidas coletâneas Hiroxima e Vietname, organizadas por Carlos Loures e Manuel Simões e publicadas respetivamente em 1967 e 1970, bem como a utilização do eco de Hiroxima em Manuel Alegre ("Nambuangongo Meu Amor"), e da guerra do Vietnam em Egito Gonçalves ("Vietnam” e “Também aqui Vietnam”), Rebordão Navarro ("Acróstico"), Carlos Loures ("Pequena crónica do tempo em que os chacais mordiam").

5 "Dorme-se e apodrece o pesadelo/ o sol nunca existiu e o resto é lodo" (CRUZ, 1961, p. 16); "sem nevoeiros asfixiamos nítidos" (JORGE, 1961, p. 3-6). Sobre a poesia de Luiza Neto Jorge, ver Fernando Cabral Martins (2000, p. 247-255).

6 Cf. RUSSO, Vincenzo. A suspeita do avesso. Barroco e Neo-Barroco na Poesia Portuguesa Contemporânea. Vila Nova de Famalicão, Quasi, 2008.

7 “mas como é que eu podia saber que o meu António havia de vir assim das Áfricas, ele que era uma pessoa, não desfazendo, de tão bom coração e desde que veio das guerras anda transtornado da cabeça e me mete medo grita noite e dia, bate-me até se fartar e eu ficar estendida. [...] António, eu quero ir-me embora e quero tanto que voltes." (BARRENO, HORTA \& COSTA, 1974, p. 209 e 245).

8 Sobre o conceito de Warburg de "Gedächtnis als Leidschatz", ver Aleida Assmann (2002, p. 411). 